\title{
Pola Adaptasi Manusia Terhadap Lingkungannya
}

\section{Sambung Widodo}

Keywords: adaptation, culture, pattern, technology, theory, environment

\section{How to Cite:}

Widodo, S. (2005). Pola Adaptasi Manusia Terhadap Lingkungannya. Berkala Arkeologi, 25(1), 69-75. https:// doi.org/10.30883/iba.v25i1.911

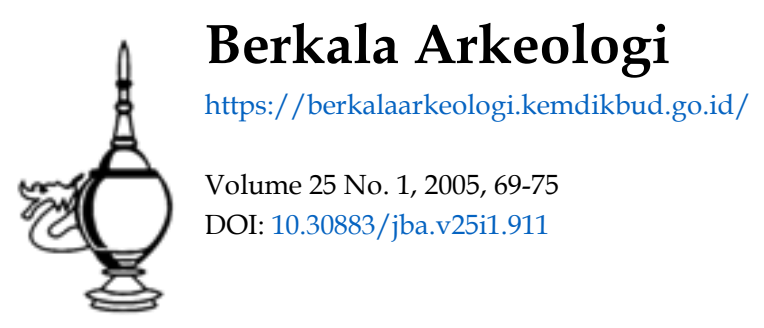

\section{(c) (1) (2)(2)}

This work is licensed under a Creative Commons Attribution-NonCommercial-ShareAlike 4.0 International License. 


\title{
POLA ADAPTASI MANUSIA TERHADAP LINGKUNGANNYA
}

\author{
Oleh: Sambung Widodo
}

\section{Pendahuluan}

Semua makhluk di bumi hidup dalam sebuah biosfer yang terdiri atas udara, air, dan daratan. Dalam wilayah kehidupan ini, manusia dengan beberapa juta spesies binatang dan sekitar 500.000 spesies tumbuhan saling berinteraksi terus menerus, dan telah membentuk wilayah planet ini selama sekitar tiga milyar tahun (TIRA Pustaka, tt).

Manusia sebagai salah satu komponen makhluk hayati hanyalah bagian kecil dari ekosistem. Dia harus tunduk kepada mekanisme terciptanya suatu harmoni ekosistem bumi, yaitu terjadinya alur energi yang saling dimanfaatkan dari jasad yang satu oleh jasad yang lainnya dan secara keseluruhan membentuk mata rantai, saling ketergantungan menggerakkan putaran energi secara serasi. Manusia sebagai makhluk bernalar dan berbudaya merasa dirinya istimewa dibanding makhluk hayati lainnya, sehingga cenderung merasa sebagai subyek ekosistem bumi. Padahal sebagai komponen ekosistem, manusia sama kedudukannya sebagai obyek seperti halnya komponen flora, fauna, tanah, air, udara, dan lainnya. Dari hukum ekosistem tersebut, maka kewajiban melestarikan sumber daya alam sudah melekat sejak keberadaan manusia itu sendiri. Manusia sebagai subyek sekaligus obyek dalam ekosistem (Achmad Sulthani, 2002).

Sejak masa prasejarah, pola adaptasi manusia terhadap lingkungannya mewujudkan pola-pola tertentu yang sangat terkait dengan strategi subsistensi manusia dalam beradaptasi dengan lingkungan alamnya. Pemilihan lokasi untuk hunian manusia sangat dipengaruhi oleh usaha untuk meminimalkan penggunaan energi dan waktu dalam mengeksploitasi dan mendistribusikan sumber-sumber subsistensi. Ada toleransi antara lokasi situs dengan pola adaptasi manusia terhadap lingkungan alamnya. Faktor yang terkait dengan kondisi lingkungan merupakan faktor yang sangat penting di dalam pemilihan lokasi, di samping faktor lain selain seperti faktor ekonomi dan politik. Beberapa variabel yang dipertimbangkan dalam pemilihan lokasi situs yang terkait dengan kondisi lingkungan antara lain dinyatakan oleh Karl W. Butzer (1964) sebagai berikut.

1. Tersedianya air, tempat berteduh dan kondisi tanah yang tidak terlalu lembab.

2. Tersedianya fasilitas untuk bergerak dengan mudah seperti sungai, pantai, rawa.

3. Tersedianya sumber makanan, baik berupa flora maupun fauna, serta faktor yang memudahkan untuk memperolehnya (batas-batas topografi, pola vegetasi). 
4. Faktor yang memberi elemen-elemen tambahan akan binatang laut atau air (dekat pantai, danau, sungai, mata air).

Pola adaptasi manusia terhadap lingkungan alamnya sangat dipengaruhi oleh tingkat pengetahuan dan teknologi yang dimiliki. Pada masa prasejarah manusia cenderung untuk memanfaatkan dan melakukan strategi subsitensinya pada tempat-tempat yang dekat air untuk kepentingan sehari-hari, sumber-sumber makanan berupa flora dan fauna, di tempat-tempat aman dan nyaman. Dengan pertimbangan beberapa faktor tersebut lokasi situs prasejarah banyak menempati tempat-tempat yang dekat dengan danau, rawa, dan aliran sungai. Untuk memperoleh tempat berlindung banyak dimanfaatkan gua atau ceruk (rock shelter). Pemilihan gua sebagai tempat hunian merupakan bukti kearifan manusia pada masa itu dalam memanfaatkan sumberdaya alam. Gua yang dipilih sebagai lokasi hunian biasanya memiliki sirkulasi udara yang baik, sinar matahari cukup, lantai yang relative rata, dekat dengan sumber makanan (flora dan fauna) dan air.

Meskipun lingkungan merupakan salah satu factor yang dominan yang mempengaruhi pola adaptasi pada masa prasejarah, tetapi pada masa yang lebih kemudian, seiring meningkatnya pengetahuan dan teknologi yang dimiliki, di samping factor lingkungan alam, factor ekonomi dan politik sangat berpengaruh terhadap pola adaptasi manusia.

Dengan semakin kompleksnya kehidupan, di mana populasi penduduk semakin meningkat, maka kebutuhan manusia semakin bervariasi yang tidak mungkin lagi dapat dipenuhi oleh lingkungan alam dalam komunitasnya. Untuk memenuhi kebutuhan hidup, manusia menjadi saling tergantung antara komunitas satu dengan yang lainnya. Pada masa itu dengan bertambahnya pengetahuan dan tingkat kemampuan teknologi yang dimiliki telah muncul spesialisasi dalam sebuah komunitas. Dengan spesialisasi tersebut manusia saling tergantung dan saling membantu dalam memenuhi kebutuhan hidupnya, sehingga bekembang sistem barter yang menjadi awal pertumbuhan sistem perdagangan. Pola adaptasinya selain dipengaruhi oleh faktor lingkungan alam, juga dipengaruhi oleh kebutuhan akan ketersediaan sarana dan prasarana yang memadai untuk transportasi dan komunikasi. Sistem perdagangan membutuhkan kegiatankegiatan administrasi yang akhirnya berkembang menjadi pusat-pusat pemerintahan. Secara politis, keberadaan pusat-pusat pemerintahan didukung oleh sector perdagangan, pertanian, perindustrian, pusat-pusat keagamaan dan pusatpusat kebudayaan.

Secara kronologis, pola adaptasi manusia terhadap lingkungan sesuai dengan pengetahuan dan teknologi yang dimiliki digambarkan oleh HR. Bimantoro (1995) sebagai berikut. 
1) "Food Gathers", yaitu para pengumpul bahan pangan dengan menggunakan alat sangat sederhana. Mereka hanya berjalan berkeliling dan mengumpulkan hasil hutan, buah-buahan atau dedaunan yang dapat dimakan.

2) "Hunting people", yaitu mereka yang sudah memanfaatkan daging hewan sebagai menu makanannya. Cara penagkapannya pun dengan menggunakan alat atau cara yang sederhana. Dalam hal ini mereka harus berani pergi lebih jauh untuk menangkap atau mengejar hewan buruannya. Di sini sudah diperlukan cara berpikir lebih luas daripada yang dilakukan oleh para "food gathers".

3) "Fisherman", yaitu mereka yang sudah berani meninggalkan tempat tinggalnya untuk menangkap ikan di sungai, di danau atau di laut, walaupun dengan sampan atau perahu dan alat jaring yang sederhana. Pemikiran dan pengalaman untuk mengetahui sumber ikan dan strategi penangkapannya sudah menunjukkan peningkatan budaya dan eko-teknologinya.

4) "Shifting cultivators", yaitu mereka yang merasa harus mempunyai mata pencaharian yang teratur dan relative menetap, sehingga pada saat itu sudah mulai mencurahkan fikirannya pada tanaman pertanian. Cara bertaninya sangat sederhana dengan cara slash and burn yang kemudian sesudah panen lahan pertanian ditinggalkan dan mulai dengan membuka lahan pertanian baru. Sistem ini dikenal dengan sistem ladang berpindah.

5) "Herding people", mereka yang sudah menjadi shifting cultivators tetapi kemudian menambah dengan memelihara ternak. Kehidupan mereka ini lebih dinamik dan golongan ini dikenal juga dengan istilah nomadic people. Untuk berpindah-pindah harus ada keberanian yang masih asing.

6) "Extensive agriculture", merupakan perkembangan lebih lanjut dari para shifting cultivators dan nomadic people. Budaya dan teknik bercocok tanamnya sudah lebih tinggi dari para peladang berpindah dan relative permanen. Perkembangan selanjutnya adalah penduduk yang melaksanakan intensive agriculture. Dalam hal ini, mereka sudah maju dalam teknologi pertanian. Demikian pula pandangan hidup dan kebudayaannya sudah jauh lebih maju

7) "Industrious people", adalah mereka yang sangat maju, bahkan sudah dapat dikelompokkan dalam bangsa yang modern. Kehidupannya serba industri dan pemikirannya praktis dan pragmatis. Suatu saat mereka mungkin meninggalkan kehidupan yang bersifat agraris. Teknologinya sangat canggih.

8) "Commercial people", adalah mereka yang kegiatannya berdagang. Sarana dan prasarana transportasi yang modern sangat mendukung kehidupan bangsa-bangsa berdagang lokal, interinsuler maupun internasional. Motto hidupnya adalah time is money. Hidup adalah bisnis.

9) "Politician", adalah mereka yang sudah memahami manfaat pendidikan, teknologi, industri, ekonomi dan lingkungan. Mereka mempunyai wawasan yang luas di bidang politik pemerintahan, politik perdagangan, politik perdagangan, dan keamanan. 
Secara umum pola adaptasi tersebut dapat dikelompokkan dalam tiga tingkatan peradaban, yaitu Masyarakat Tradisional, Masyarakat Agraris, dan Masyarakat Industri.

\section{Pengaruh Pola Adaptasi terhadap Ekosistem.}

Pola adaptasi manusia terhadap lingkungannya menunjukkan perkembangan peradaban yang begitu cepat, berlari dari masyarakat primitif menuju masyarakat agraris, ke masyarakat industri yang modern. Pola adaptasi setiap tahap tersebut sangat berpengaruh terhadap kelestarian ekosistem.

\section{Mayarakat Primitif}

Pada awal kehidupan manusia yang masih sangat sederhana, pola adaptasinya masih bersifat subsisten yaitu perilaku tradisional yang orientasi utamanya adalah untuk pemenuhan kebutuhan sendiri (survive), sehingga ekosistem alami relative tidak banyak perubahan. Dalam kondisi yang alami hampir tidak ada musibah, karena dalam ekosistem yang seimbang berbagai unsur potensi biotik bekerja dan berfungsi dengan baik. Macam-macam potensi biotik alami selalu diimbangi oleh resistensi lingkungan (environtmental resistence). Dalam ekosistem alami, unsur-unsur biotik masing-masing mempunyai fungsi sebagai pengendali keseimbangan lingkungan, unsur-unsur biotik tidak pernah ada yang mendominasi, sehingga terjadi ekosistem yang stabil dan seimbang (homostatis).

\section{Masyarakat Agraris}

Pada tahap berkembangnya budidaya pertanian, di mana dengan kemampuan teknologi yang dimiliki, manusia berusaha untuk meningkatkan produktifitas hasil pertanian, sangat berpengaruh pada ekosistem. Bagaimana proses pengaruh tersebut dapat digambarkan dalam table berikut (Nurhadi: 1995).

Dalam budidaya pertanian, kemajuan teknologi yang mempunyai dampak terhadap ekosistem disebabkan karena beberapa hal antara lain simplifikasi dan intensifikasi. 
BUDAYA PERTANIAN

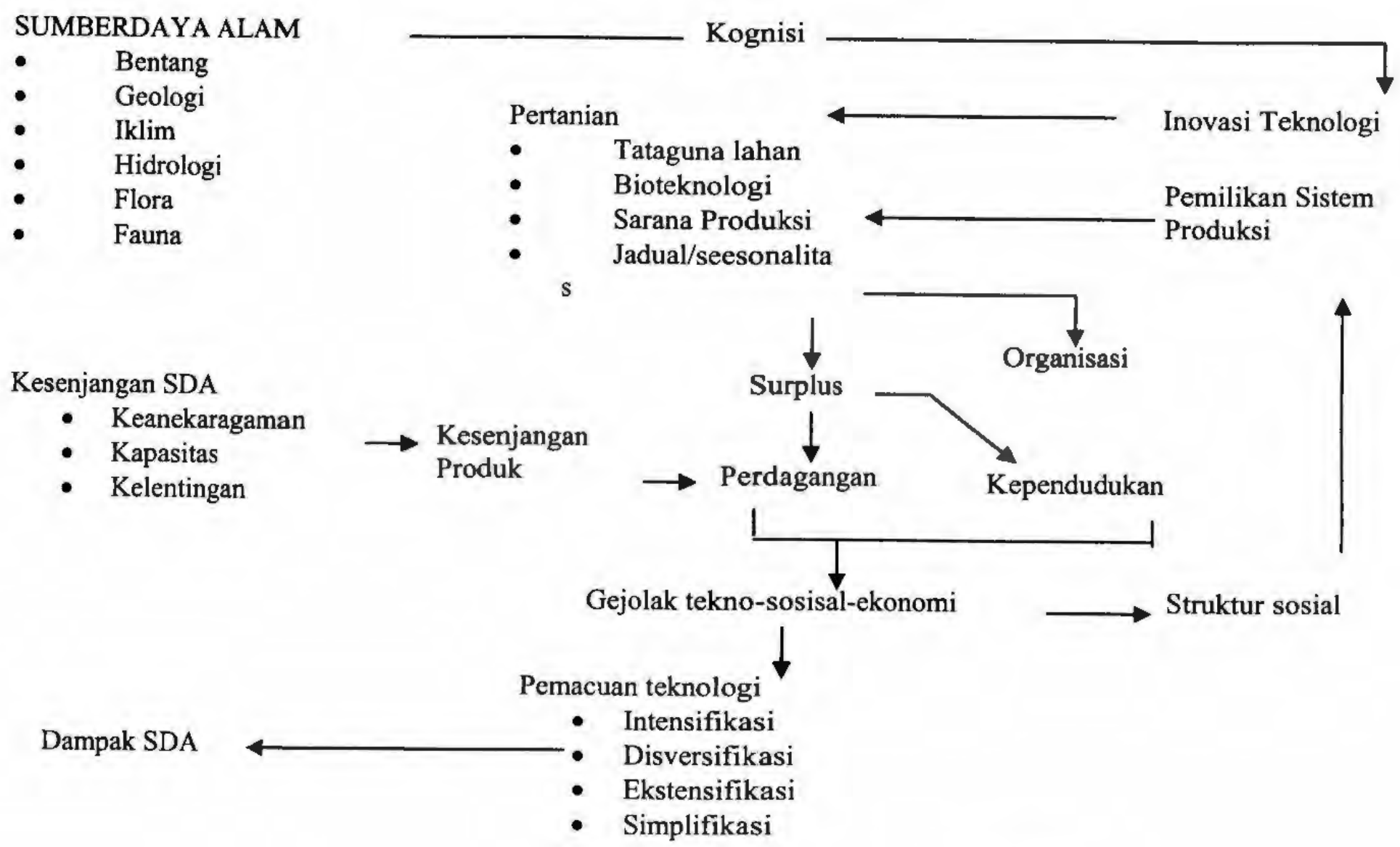

Berkala Arkeologi Th. XXIV 
Intensifikasi dengan menggunakan bahan-bahan kimiawi sangat merusak ekosistem. Pengguna insektisida misalnya, meskipun memberikan manfaat dengan meningkatnya jumlah produktifitas namun membawa dampak ekologis yang sangat merugikan. Pengendalian hama penyakit dengan insektisida menimbulkan deposisi senyawa-senyawa beracun pada tanaman dan binatang. Bahkan, terjadi penetrasi ke dalam jaringan tanaman dan hewan yang kemudian dikonsumsi manusia. Di samping itu penggunaan pestisida mengakibatkan pencemaran pada tanah dan perairan, sehingga pertumbuhan tanaman terhambat, ekosistem berubah, biota di danau dan sungai berubah, beberapa organisme mati, microorganisme-pathogens dan fauna tanah merubah aktivitas dan pola hidupnya dan mempengaruhi kesehatan manusia (Sulthoni, 2002). Di samping itu pengembangan tanaman pangan secara intensif dengan memanipulasi bibit dan memodifikasi habitat telah menyebabkan degradasi genetis sumber plasma nuthfah. Hal ini telah menjadi keprihatinan bagi para ahli lingkungan dan ahli petanian yang peduli pada masa depan pertanian berkelanjutan (Baiquni:2003).

Oleh sebab itu penelitian terus dikembangkan, baik di bidang pertanian maupun ekologi untuk mencari metode pengendalian hama dan peningkatan produktivitas yang ramah terhadap lingkungan, guna menjamin kelestarian ekosistem. Pengembangan dan inovasi teknologi yang diaplikasikan tanpa mempertimbangkan kelestarian ekosistem alami dapat berakibat fatal. Dalam arti pengembangan tersebut dapat menjadi bumerang dengan menurunnya kualitas lingkungan dan kehidupan manusia itu sendiri.

\section{Masyarakat Industri}

Di era industrialisasi, perkembangan pengetahuan dan teknologi telah membawa manusia mampu melakukan perubahan besar-besaran, baik dalam rekayasa industri maupun pemanfaatan sumberdaya alam. Semua itu dilakukan demi memenuhi kebutuhan manusia, yang populasinya sampai saat ini mencapai 6 milyar jiwa, yang semuanya membutuhkan pangan, sandang, dan papan.

Dalam sejarah perjalanan peradaban manusia di era industrialisasi, menunjukkan adanya dampak-dampak yang amat mencengangkan, karena telah menimbulkan masalah keterbatasan ketersediaan pangan, kelangkaan dan pencemaran air, kelangkaan sumber energi, polusi udara, dan berbagai kerusakan sumberdaya alam lainnya. Manusia saling berkompetisi untuk mencapai pemenuhan kebutuhan. Bahkan ada yang saling berlomba memenui ambisinya dengan mengeksploitasi sumberdaya alam. Akibat dari ulah manusia tersebut muncul kekhawatiran akan datangnya bencana ekologis yang dapat menyebabkan daya dukung kehidupan hancur dan sulit untuk dipulihkan lagi. 
Contoh kasus kerusakan ekologis yang terjadi pada masyarakat industri antara lain karena eksploitasi yang berlebihan terhadap hutan. Fungsi dan manfaat hutan hanya dipandang sebelah mata dari sisi ekonomis, seperti untuk kepentingan produksi kayu, rotan, dan sumber eksport macaca fascicularis. Kesemuanya itu hanya merupakan nilai tangible dari fungsi hutan. Sementara itu, nilai manfaat kelestarian dan keberlanjutan ekosistem yang merupakan nilai ekologis yang berjangka panjang (intangible benefit) sangat diabaikan.

Beberapa konsekuensi yang ditimbulkan dari perlakuan tersebut telah menimbulkan penurunan biodeversitas, kerusakan plasma nutfah, dan terganggunya habitat fauna. Akibat lebih lanjut adalah terjadinya bencana kebakaran hutan, polusi udara, kelangkaan sumber air, banjir, dan tanah longsor.

Faktor lain dari kerusakan hutan juga disebabkan karena pembukaan lahan untuk pertanian (ekstensifikasi), perluasan pemukiman penduduk, dan kepentingan industrialisasi yang lain. Keadaan ini merupakan proses insularisasi, yaitu proses terisolasinya suatu komunitas biologis yang pada akhimya berpengaruh terhadap keanekaragaman biologis. Secara bertahap proses tersebut menyebabkan kepunahan species flora dan fauna (Sulthoni, 2002).

\section{DAFTAR PUSTAKA}

Anonim. t.t. Ekologi dan Lingkungan. Tira Pustaka, Jakarta.

Baiquni. M. dan Susilawardani. 2003. Pembangunan yang Tidak Berkelanjutan, Refleksi Kritis Pembangunan Indonesia. Transmedia Global Wacana, Yogyakarta.

Bintarto, H. (1995). Keterkaitan Manusia, Ruang Dan Kebudayaan. Berkala Arkeologi, 15(3), 1-4. https://doi.org/10.30883/jba.v15i3.663

Butzer, Karl W. 1964. Environment and Archaeology: An Introduction to Pleistocene Geography. Aldine Publishing Company, Chicago.

Nurhadi, nfn. (1995). Pasang Naik Dan Surut Kota-Kota Pantai Utara Jawa, Sebuah Model Kajian. Berkala Arkeologi, 15(3), 87-91. https://doi.org/10.30883/jba.v15i3.677

Sulthoni, Achmad. 2002. Cakrawala Konservasi Sumberdaya Hutan. Fakultas Kehutanan UGM, Yogyakarta. 